\title{
Harsh Reality of Chauvinistic Patriarchial World: Ambivalence of Objectified Second Sex after Rebellious Self-Assertion
}

\author{
Dr. Surete \\ Ph.D. Mewar University \\ Gangrar, Chittorgarh, Rajasthan, India \\ gsureeti@gmail.com
}

Abstract

In this paper efforts have been made to show the mixed feeling that comes in the mind of an Indian woman when she realises her worth. The chauvinistic world is using woman as an object to fulfil the desires since ages. Indian women are brought up in such atmosphere that they find it difficult to face men and like a dumb cattle obey all the orders of man, be it their father in childhood, their husband after marriage or their son in old age. She is never asked or allowed to express her own will and when she tries to take the decisions in her own hands she is tortured and insulted with taunts. This paper highlights the feelings of women when she faces such situation. In this paper a deep study of three plays of Vijay Tendulkar has been done which are Kamala, Silence! The Court Is In Session and Kanyadaan .

Keywords: Chauvinistic Society, Objectification of Women, Rebellious Self Realization, Patriarchic World, Biased Set of Rules.

The best thing about the Literature is that it reflects the society and the human nature, merits and demerits of social, political and various worldly structure and dynamics of society and human relations in various fields. Various writers represent the society in their writings giving a clear idea about various conditions and happenings of the world. My work deals with Indian English literature, chiefly with the work of Marathi playwright Vijay Tendulkar. After 
a deep study of the plays written by him it is clear that in his works dynamics of human relationships has been clearly picturised. In the present paper an attempt is made to present the condition of women in the patriarchial society. Three plays of Tendulkar Silence! The Court Is In Session, Kamala and Kanyadaan are taken into account which clearly picturise the condition of the women. Women who are the real architects of society are considered as weaker sex in this male dominated world. It is clear that women are the building blocks of the society. According to Cher, "Women are the real architects of society". But it is very sad and pathetic to administer that their marginalization and objectification considering them as the second sex is going on since ages. It is clearly visible when Iric Murdoch comments , "I think being a woman is like being Irish...Everyone says you're important and nice, but you take second place all the time".

In the play Silence! The Court Is In Session, it is Miss Benare alone who is questioned, insulted, mistreated and all the guilt is put on her alone. No one questions Prof. Damle who is also equally responsible for the adultery act. Damle neatly escapes out and all the humiliation is faced by the woman Miss Benare only. This world is governed by patriarchy which is clearly visible when Emmeline Pankhurst suggests, "Men make the moral code and they expect women to accept it. They have decided that it is entirely right and proper for men to fight for their liberties and their rights, but that is not right and proper for women to fight for theirs." Chauvinistic male dominated society has been biased towards women and men have a different set of rules which is not applicable on the feminine world. Beena Agarwal aptly comments, "Silence! The Court Is In Session: A Process of the Construction of Feminine Identity, is a suggestive analysis of the apathy of societal conventions towards a woman." During the trial scene of Miss Benare she faces all the humiliation alone. Beena Agarwal rightly comments, "This simple episode becomes a matter of serious discussion and every member of the jury becomes anxious to determine exactly 
how much time would be needed in spitting business." Just as a man chews the pan, enjoys its sweetness and in the end he spits out the leftover, same is done in the case of Benare. Her situation becomes ridiculous, crude and horrible and she seems to the world just like the spit of pan masala which Damle throws away in the trash after the work is done. In the play Benare desperately interprets, "Is this a court of law, Karnik or a spitting contest." (77) During the mock trial Miss Benare, under Section 302 of the Indian Penal Code is accused of crime of infanticide which can be clearly seen when Kashikar questions Benare, "Are you guilty or not guilty of the aforementioned crime?" (78)

Anju Bala Agarwal aptly remarks, "Silence descends on her when the mock-trial begins with Kashikar's sudden interrogative statement." She explaining the helpless condition of Benare further adds, "Benare is dumb founded. She increasingly seeks shelter in her self-imposed silence. Her protests to charges are drowned in Kashikar the mock-judge's imposition: Silence! In such a helpless and hostile situation, Benare has no other choice but to remain silent". The oppression of a man is considered a tragedy however that of a woman is seen as a tradition. It is a society where no one tries to understand the plight of a woman. They are just used and thrown according to the choice of patriarchy. This is clear from when Oscar Wilde says, "Women are meant to be loved, not to be understood." However Anju Bala Agarwal further expresses her thoughts about the cyclone of thoughts that was going into Benare's mind. She says, "Benare breaks her forced silence at the close of the play, when she bursts forth into a long and brilliant monologue which brings out in most eloquent terms...This stunning monologue exposes the hypocricy of the urban middle-class male chauvinists who have all ganged up against her, as they are envious of her confidence and uncompromising spirit of independence." (198)

In our next play Kanyadaan, we critically study the character of Jyoti who is a softspoken and highly cultured girl from a Brahmin family. She marries Arun, who is a dalit boy 
suffering from an inferiority complex because of being from a lower caste as compared to her wife Jyoti. We also examine transformation in Nath's attitude who is Jyoti's father. Due to bitter experiences in life a stubborn idealist turns into a disillusioned realist. Nath happily allows Jyoti to marry Arun because it was his dream to create an egalitarian, humanitarian society and bridge the social gap of casteism in the society. Shailaja B. Wadekar quotes about Nath, "Jyoti's decision to marry Arun provides him an opportunity to follow in the footsteps of the old social reformers who not only delivered speeches and wrote articles on the remarriages of widows but also married them." Thus we can feel that for him Jyoti's marriage with Arun was a kind of social experiment, where he sacrifices his daughter's life just to prove his thinking and ideology to the world. After Jyoti got married to Arun followed a storm of violence and hatered. N.S. Dharan writes, "What follows is a sequence of violence, misery, and disillusionment."(88) Shilpi Rishi Srivastava quotes, "It is a human psychology that oppressed are overjoyed when they get a chance to oppress others." (109) After marriage Arun used to behave in a brutal manner with Jyoti and there was no option for Jyoti but to admit her fate.

She blames her father for her fate because he experimented with Jyoti's life just to prove the power of his idealistic thinking. It is clear in Jyoti's speech as she expresses her fury and rage for her father as she blames him saying, "It is essential to awaken the god slumbering within man...' All false, vicious claptrap! The truth is, you knew very well that man and his inherent nature are never really two different things. Both are one, and inseparable...Putting man's beastliness to sleep, and awakening the godhead within is an absurd notion. You made me waste twenty years of my life before I could discover this. I had to learn it on the strength of my own experience." (563) Jyoti before marriage is used by her own father as a puppet for his social experiment and after marriage she was tortured and beaten by her husband Arun. Jyoti finally leaves her father's world and accepting her fate 
she expresses her anger saying, "I am not Jyoti Yadunath Devalikar now, I am Jyoti Arun Athavale, a scavenger. I don't say harijan, I despite the term. I am an untouchable, a scavenger, I am one of them. Don't touch me. Fly from my shadow, otherwise my fire will scorch your comfortable values."(566) In reference to aforesaid Jyoti's speech Charlie Kaufman remarks about Jyoti's condition as he writes, "I'm not a concept. Too many guys think I'm a concept or I complete them or I'm going to make them alive, but I'm just a fucked up girl who is looking for my own peace of mind. Don't assign me yours." Thus, we see here how Jyoti is used as a puppet by her father for his social experiment knowing clearly that it will destroy his daughter's life. After marriage she is mistreated by Arun her husband who objectified her to fulfil his lusty desires. Elizabeth Peters express her views about marriage as she declares, "I disapprove of matrimony as a matter of principle....Why should any independent, intelligent female choose to subject herself to the whims and tyrannies of a husband? I assure you, I have yet to meet a man as sensible as myself!" In the end Jyoti is left helpless and her condition and plight is very well expressed in Betty Friedan quote as she accepts, " It is easier to live through someone else than to complete yourself. The freedom to lead and plan your own life is frightening if you have never faced it before. It is frightening when a woman finally realises that there is no answer to the question 'who am I' except the voice inside herself."

The play Kamala, is a story which is inspired by a real-life incident when a journalist Ashwin Sarin tries to gain position in society, buys a girl from the rural flesh market just to prove the human trade existing in the society. In the play the journalist Jaisingh Jadhav's selfish hunger for power and position makes him to purchase a woman Kamala who is further exposed in the press conference. He does not care what will happen to Kamala after this expose. Arundhati Banerjee exposing Jaisingh's selfishness says, “Jadav never stops to think what will happen to Kamala after this expose" (581). She further adds, "Kamala is an 
indictment of the success-oriented male-dominated society where women are often victims or stepping stones in men's achievements" (583). Selfishness of Jaisingh Jadav can be clearly seen when he says, "I just wanted to present her as evidence. And that was done." (30)

Lisa Kemmerer remarks, "The reproductive abilities of women and other female animals are controlled and exploited by those in power (usually men) and both are devalued as they age and wear out - when they no longer reproduce. Cows, hens and women are routinely treated as if they were objects to be manipulated in order to satisfy the desires of powerful men, without regard to female's wishes or feelings". In reference to this Arundhati Banerjee comments, "Like Kamala, Sarita is also an object in Jadav's life, an object that provides physical enjoyment, social companionship and domestic comfort." (581) Shibu Simon comments on the objectification of women, "The play Kamala deals with the problem of women being treated as a commodity in the modern world. Both Kamala and Sarita are commodities that can be sold off. In a country like India, the fate of a woman - whether tribal or urban or educated - is basically the same."(190). He further adds, "From birth, a girl is subjected to the negative reinforcement of her vulnerability to rape and assault. As a girl, she is under the protection of her father or brother; after marriage her husband is her lord and master and in old age her son becomes her protector." (191)

The aforesaid fact is further proved when Barbara Kingsolver presents her views, "Until that moment I'd thought I could have it both ways; to be one of them, and also my husband's wife. What conceit! I was his instrument, his animal. Nothing more. How we wives and mothers do perish at the hands of our own righteousness. I was just one more of those women who clamp their mouths shut and wave the flag as their nation rolls off to conquer another in war. Guilty or innocent, they have everything to lose. They are what there is to lose. A wife is the earth itself, changing hands, bearing scars." A man thinks that a woman is like a clay toy that can be moulded according to his wish. In this regard Bonnie 
Burstow writes, "Man looks on woman from his vantage point and reduces her to a being that is not for - itself but for - him." Same idea has been expressed by Glennon Doyle as he concludes, "We weren't born distrusting and fearing ourselves. That was part of our taming. We were taught to believe that who we are in our natural state is bad and dangerous. They convinced us to be afraid of ourselves. So we do not honour our own bodies, curiosity, hunger, judgement, experience, or ambition. Instead, we lock away our true selves. Women who are best at this disappearing act earn the highest praise: She is so selfless. Can you imagine? The epitome of womanhood is to lose one's self completely. That is the end goal of every patriarchial culture. Because a very effective way to control women is to convince women to control themselves." But the moment a women realises her self-worth no one can dare to control her. This concept is clearly presented by Mark Anthony where he concludes, "And one day she discovered that she was fierce, and strong, and full of fire, and that not even she could hold herself back because her passion burned brighter than her fears." Patriarchial control over woman seems to be the never ending thing. Whenever women tries to speak up for themselves, they are made to shut their mouths. Rebecca Solnit expresses her views about the aforesaid fact as she speaks, "Every woman knows what I'm talking about. It's the presumption that makes it hard, at times, for any woman in any field; that keeps women from speaking up and from being heard when they dare; that crushes young women into silence by indicating, the way harassment on street does, that this is not their world. It trains us in self-doubt and self-limitation just as it exercises men's unsupported confidence." When Kamala enters into Sarita's life, her innocent questioning makes Sarita realise that she too is a toy in the hands of her husband. Arundhati Banerjee exposes this fact in her quote, "Kamala's entry into the household reveals to Sarita the selfish hypocricy of her husband and the insignificance of her own existence."(581) 
W.E.B. Dubois suggests, "There is no force more powerful than a woman determined to rise." In the above context we find that Sarita's self -realization is clearly visible in her speech as she says, "I am going to present a man who in the year 1982 still keeps a slave, right here in Delhi. Jaisingh Jadhav. I'm going to say: this man's great advocate of freedom. And he brings home a slave and exploits her. He doesn't consider a slave a human being just a useful object. One you can use and throw away. He gets people to call him a sworn enemy of tyranny. But he tyrannizes his own slave as much as he likes, and doesn't think anything of it-nothing at all. Listen to the story of how he bought the slave Kamala and made use of her. The other slave he got free - not just free - the slave's father shelled out the money - a big sum. (46) Same thought about a strong and confident woman is beautifully penned down by Carrie Green, "I can and I will. Watch me." Here Sarita feels herself in the position of a slave who is being used by her master since the time she got married to him. But we find that women are raised up in such a manner that even after realising their value they are not able to take the step and speak up openly against the injustice done to them. Arundhati Banerjee further comments on the seriousness of the situation as she expresses her views saying, "Like most of Tendulkar's sympathetic women characters, she does not have the spirit to rebel against her present condition. Instead, she extends emotional support to Jadav when at the close of the play he is treacherously deprived of his job."(581) Now call it the weakness or call it the greatness of a woman that she is so much devoted towards her duty that she overlooks every injustice done to her. In reference to the undomitable power of a woman Arundhati Banerjee further adds, "Sarita cannot unlearn what she has come to realise and at the end of the play there is a faint hope of her attaining independence sometime in the future." (581) Melinda Gates truly speaks about the strength of a woman, "A woman with a voice is by definition is a strong woman...But the search to find that voice can be remarkably difficult." We cannot call it Sarita's weakness to stay quiet and give a helping hand to her 
husband when he lost his job. Infact it is her greatness and deep, true devotion for Jaisingh being his loyal wife. This is a remarkable quality of a woman about which Samuel Lowe says, "Sometimes it's the princess who kills the dragon and saves the prince."

Thus in the paper after critically analising all three female characters it would not be wrong to say that woman has ample strength and confidence hidden within herself. What is required is just the self-realization of her hidden worth. However after realising their true identity women stop themselves from moving ahead taking the bold steps against the injustice and misbehave done towards them. It is not because they are afraid of the consequences but because since birth they are being taught to fulfil their duities with complete loyalty and devotion. This is the only weakness of women that they value their ideals more than their self-respect. True is said about the devotion of woman by Cook Elizabeth in her lyrics Sometimes It Takes Balls To Be A Woman, where she says, “ Sometimes it takes balls to be a woman, Standing up to a test, while wearing a party dress." Conclusion

Women is the foundation of this human society. She is like the building block of the human world. A woman should not be considered weak just because she stays cool and calm and respects the emotions and feelings of others. Infact woman is the strongest of all because she has a lot of patience that she faces all the torments and tortures and insults alone quietly. It would also not be wrong to say that once she decides something and takes firm decision no one can stop her from getting what she wishes to achieve. 


\section{Works Cited}

Agarwal Beena, Preface to Dramatic World of VIJAY TENDULKAR Explorations \& Experimentations. Aadi Publications, Jaipur.2012. Print.

Agrawal Beena. Silence! The Court Is In Session: A Process of the Construction of Female Voice, in Dramatic World of VIJAY TENDULKAR Explorations \& Experimentations. Aadi Publications, Jaipur. 2012. Print.

Agarwal Anju Bala, Dramatic Techniqueof Vijay Tendulkar's Plays, in The Plays of Vijay Tendulkar Critical Explorations. Ed. Barbuddhe Satish and Amar Nath Prasad. Sarup \& Sons, New Delhi, 2008. Print.

Anthony Mark, The Beautiful Truth, Createspace Indeependent Publishing Platform, United States, 2016, Print.

Banerjee Arundhati, APPENDIX I, Note on Kamala, Silence! The Court is in Session, Sakharam Binder,The Vultures, Encounter in Umbugland, in Vijay Tendulkar's Collected Plays in Translation, Oxford University Press. 1992. Print.

Burstow Bonnie, Radical Feminist Therapy: Working in the Context of Violence, Sage Publications, Inc. New York. 1992. Print.

“Cher Quotes.” BrainyQuote.comBrainyMedia Inc, 2020.27 March 2020.

http://www.brainyquote.com/quotes/cher_126853

Doyle Glennon, Untaimed, The Dial Press. New York.2020. Print.

Dubois W.E.B. http://www.pintrest.co.uk/pin/268808671495310992/

Elizabeth Cook, http://www.metrolyrics.com/sometimes-it-takes-balls-to-be-a-woman-lyrics$\underline{\text { cook-elizabeth.html }}$

Friedan Betty, Goodreads.

http://www.goodreads.com/quotes/41699-it-is-easier-to-live-through-someone-else-than-to Gates Melinda, http://www.pintrest.com/pin/215821007114945988/ 
Green Carrie, http://www.pintrest.co.uk/pin/442267625891085806/

Kaufman Charlie, Eternal Sunshine of the Spotless Mind: The Shooting Script. Newmarket Press. New York. 2004. Print.

Kemmerer Lisa, Speaking Up for Animals: An Anthology of Women's Voices. Paradigm Publishers, United States. 2011, Print.

Kingsolver Barbara, The Poisonwood Bible, Harper Perennial Modern Classics, New York, 2005. Print.

Lowe Samuel, http://www.goodreads.com/quotes/7032985-sometimes-it-is-the-princesswho-kills-the-dragon-and-saves

N.S. Dharan,The Plays of Vijay Tendulkar, Creative Books, New Delhi, 1999. Print.

Pankhurst Emmelin, My Own Story, Virago Press. London.1979. Print.

Peters Elizabeth, Crocodile on the Sandbank (Amelia Peabody \#1), Grand Central Publishing. New York. 1975. Print.

Siman Shibu, Man-Woman Relationship in the Plays of Tendulkar, Critical Explorations. Ed. Barbuddhe Satish and Amar Nath Prasad. Sarup \& Sons, New Delhi, 2008. Print.

Solnit Rebecca, Men Explain Things to Me, Balzer+Bray, New York. 2014. Print.

Srivastava Shilpi Rishi, Kanyadan:The Admission of Defeat and Intellectual Confusion, in The Plays of Vijay Tendulkar Critical Explorations. Ed. Barbuddhe Satish and Amar Nath Prasad. Sarup \& Sons, New Delhi, 2008. Print.

Tendulkar Vijay, Silence! The Court is in Session, translated by Priya Adarkar, in Collected Plays in Translation, with an Introduction by Samik Bandyopadhyay, Oxford University Press, New Delhi. 2003. Print.

Tendulkar Vijay, Kamala, translated by Priya Adarkar, in Collected Plays in Translation, with an Introduction by Samik Bandyopadhyay, Oxford University Press, New Delhi. 2003. Print. 
Tendulkar Vijay, Kanyadaan, translated by Gowri Ramnarayan, in Collected Plays in Translation, with an Introduction by Samik Bandyopadhyay, Oxford University Press, New Delhi. 2003. Print.

Wadikar B.Shailaja, The Theme of Casteismin Vijay Tendulkar's Kanyadan, in The Plays of Vijay Tendulkar Critical Explorations. Ed. Barbuddhe Satish and Amar Nath Prasad. Sarup \& Sons, New Delhi, 2008. Print.

Wilde Oscar, Lord Arthur Savile's Crime and Other Stories, Penguin Books Publishers, New Delhi.1994.Print.

http://www.goodreads.com/quotes/82506-i-think-being-a-woman-is-like-being-irish-

everyone 